\title{
Demanding Politics
}

\section{Adam Rosen-Carole}

\begin{abstract}
Derrida's interest in implicating the serious in the frivolous and vice versa, or more broadly, what one might call his writerly shamelessness, evinces an exorbitant narcissism, a writerly ethos of refusing censorship, an "hyperconceptual" penchant for excess that seems to both condition his truly unparalleled and startlingly acute insights, but also to suffuse his texts with so many loose threads and frayed edges that these texts cannot but seem suspiciously underdeveloped, or brittle in their very grandiosity - as if something were being hidden, or perhaps avoided, by means of their unlimited capaciousness. This paper poses the question of whether Derrida's writerly impudence, the iconoclastic dimension of deconstruction, squares with the requirement of mutual authorization to critique constitutive of normativity. If Derrida's writerly practice is as given to unregulated and unregulatable excess as it seems, might there be an at once anti-democratic and philosophically problematic aspect to its seemingly anti-authoritarian ethos of unlimited affirmation? The question will be whether the "consumption of concepts that it produces as much as it inherits" renders deconstruction, by virtue of its nominalism, a form of nihilism - a creative consumerism.
\end{abstract}

Keywords: Derrida, democracy, aporia, dissemination

W hence and what to make of the experience of Derrida's promise? Whence and what to make of the breakneck enthusiasm, even euphoria, that his writings both embody and inspire: the audaciously arrogated license to put into play marginal moments, unconsolidated currents, rhetorical proclivities, and performative parapraxes, generally, textual ephemera, and to play them off against the official ambitions and self-understandings of the texts under consideration; or the quasi-surrealist insouciance emanating from unbidden textual juxtapositions and encouraged by the minor shocks of revelation issuing from these daring conjunctions, and perhaps further emboldened by the largerscale yet quiet tremors to which these shocks conduce? Whence and what to make of the exhilarating waves of displacement coursing through these texts,

(c) 2015 Adam Rosen-Carole

http://www.kritike.org/journal/issue 16/rosen-carole june2015.pdf

ISSN 1908-7330

(cc) $\mathrm{BY}-\mathrm{NC}-\mathrm{ND}$ 


\section{DEMANDING POLITICS}

overcoming us like a flood-the experience, somehow wanted, of barely staying afloat and sometimes going under, as wave after wave surges, overtakes us, and washes away the boundary markers in relation to which, whether wittingly or no, we had previously acquired our bearings? Whence and what to make of the affective and ethico-theoretical affirmation, that is, in Derrida's idiom, the experience of the openness to transformation of what seemed assured, of the excess of inheritance and futurity disrupting in advance the consolidation of any individual or collective identity, the sense of masochistic gratitude in the face of forces mandating self-relinquishment?

Whence and what to make of the quasi-surrealist, or more broadly, anti-authoritarian rebelliousness regarding form evident everywhere in these writings - the perspicuous liberty of genre jumping and of innovative textual assemblage, the liberality of neologism, paleonymy, polysemy, equivocation, and dissemination; the extravagant overloading of texts with multiple, untotalizable perspectives or voices, indeed the incitement to or ratcheting up of aporia? Whence and what to make of the inspiring suggestion of an extraordinary, even inexhaustible, potentiation of thought issuing from extreme textual hypercompression; the as-if-unstoppable momentum of thought spilling over into the inceptive schematizing of lines of research that there is never time or world enough to develop and thus that dangle enticingly on the horizon of a possible inheritance? Whence and what to make of the daring engagement with manifestly unserious or otherwise objectionable motifs, or more generally, the daring relinquishment of selfpossession and risking of disciplinary abjection, indeed of cultural disrepute and dismissal, even the risking of intelligibility altogether for the sake of heeding, which is to say, probing and imaginatively, attentively exploring the impulses of thought-for instance, the idiomatic, borderline idiotic constructions by which Derrida frequently finds himself claimed, indeed fixated, and to the analysis and development of which, it might be said, whole texts are dedicated? Whence, then, and what to make of Derrida's drivenness? Whence and what to make of the contagiously self-confident imaginativeness, the semantic, syntactic, and strategic liberality of these writings, their resistance to and all but iconoclastic repudiation of the questions and topics traditionally or contemporaneously prioritized in the relevant reception-traditions of the texts to which Derrida attends with such hypercritical vigilance? Whence and what to make of a capaciousness of interest so unlimited as to suggest the climate of the curious child forever intrigued by its object world and suspicious of the officious adult world and its disciplinary demands; the wonderstruck experience of witnessing the excavation of ontological infrastructures long sedimented under layers of metaphysical construction and encrusted within routine forms of thought, practice, and institutional life, and more, of being afforded a passkey with

(c) 2015 Adam Rosen-Carole

http://www.kritike.org/journal/issue 16/rosen-carole june2015.pdf

ISSN 1908-7330

(c) $)$ BY-NC-ND 
which to unlock trajectories of thought repressed or censored, curtailed but not extinguished by longstanding metaphysical priorities and proprieties thus, in a way, being on "the right side of history," namely, on the side of the vanquished? Whence and what to make of the application- or iterationfrenzy, the dizzying delight and experience of investiture in finding that basic deconstructive thought-forms or patterns of attention that can get traction in an exceptionally wide and diverse field of discourses, institutions, and practices-from philosophy to law to literature to politics to art and architecture to gender, race, sexuality, and class, to theology and religion to historiography to neuroscience and contemporary biology to psychoanalysis, and so on? Whence, then, and what to make of the experience of Derrida's promise?

Of course, it is news to no one that Derrida's writings have provoked their fair share of frustration, consternation, condescension, disbelief, and contempt; indeed, such writings have occasioned an anomalous, while not unprecedented, outpouring of vitriol. But I wonder whether the liberty with which yet another insulting and largely undiscriminating invective is launched, the self-arrogated license to heap abuse upon these writings is cleanly separable from the experience of their promise. By no means do I want to suggest that censorious critique or maliciously uninformed invective, in its haste to disparage and dismiss, merely symptomatizes the anxious registration of a "dangerous truth." I very much doubt that repudiation and aggressive neglect either always, or in the case of Derrida's negative reception in particular, register a threat to be warded off, and so betray a lack of selfconfidence, an incipient awareness of difficulties with one's own commitments otherwise occluded by, indeed disguised in the form of the bravado of self-assertion and institutional closing of ranks. So I am not claiming, as the old cliché about resisting psychoanalytic interpretation would have it, that the negative reception of Derrida is merely resistance, thus, an oblique testimony to the difficult truth of what is aggressively disclaimed or quickly glossed over and rejected. But neither am I certain that polemicizing against Derrida is merely a rappel à l'ordre. Perhaps Derrida's promise and the liberties taken in arrogantly demeaning and dismissing his work draw from the same source; they are inseparable, though hardly indistinguishable, offshoots of a common root. Call that root, for the moment, nihilism, which is to say, disenchantment, thus Enlightenment, or if you prefer, modernity. As this cannot but sound much more provocative than I mean it to be, let us then try an older word: nominalism. Or perhaps a more familiar phrase: the truth of skepticism. But as these rephrasings hardly allay the provocation I would rather avoid, let me suggest another way of thinking about the convergence of Derrida's promise and his easy dismissal or aggressive debasement. Perhaps both the promise and the disdain evince a

(C) 2015 Adam Rosen-Carole

http://www.kritike.org/journal/issue 16/rosen-carole june2015.pdf

ISSN 1908-7330

(cc) BY-NC-ND 


\section{DEMANDING POLITICS}

fundamental disrespect. Having in common this disrespect, they draw on their disrespect though differently-in Derrida, disrespect takes shape as impudence, impertinence, and unabashed self-authorization, while in the vituperations of his more brazen critics, disrespect takes shape as a somewhat disingenuous outrage, the outgrowth of an unplaceable annoyance. Certainly they both take liberties, Derrida as much as his critics. And this being-atliberty is what I mean to call attention to. If I were to offer anything like a symptomatology of Derrida's negative reception, I might be tempted to say that the wild outpouring of derision and self-confidence bolstering condescension toward Derrida's work registers the disrespect embodied in that work however swathed in the etiquette of adventurous French philosophy it might be. Though ethical perhaps to a fault and generous beyond belief, though very rarely given to malicious barbs or to aggressively self-promoting, thus other-diminishing, overestimations of his accomplishments, indeed quite tasteful in his weaving of thoughtful impertinence into magnificent textual tapestries, Derrida answers to no one. Just consider the unending difficulty of attempting to pin down what questions he is addressing or registers he is working in at any moment, or what the conceptual entailments of his claims, concepts, or nonconcepts might be, let alone what the overall ambitions of his works might be. To write in a way that demands judgment is one thing - all modernist works aspire to autonomy and so demand judgment as a condition for the appreciation of their unprecedented accomplishments. But to write in a way that is so equivocal as to answer more or less equally well to any number of ideas about what the writing is up to, to court or even to taunt the question of infinite regress is something else. That Derrida answers to no one is, perhaps, the intolerable disrespect replayed in his critical chastisements.

So the question is, again, whence and what to make of the experience of Derrida's promise. Whence and what to make of his adeptness at infusing sturdy conceptual architectures and long-entrenched horizons of philosophical ambition with open-ended possibilities, and the fascinated interest and uncanny optimism, indeed the faith and hope, this inspires?

In view of this question of faith and hope, allow me to open a brief parenthesis. Following Derrida's death, melancholic trends of incorporation and refusal of loss, by which I mean performances of fidelity to the master and giving way to anecdote among those who should, and do, know better, were remarkably prevalent, even the predominant form of grieving. I suspect that these melancholic trends had something to do with the loss of the faith and hope that Derrida's writings had inspired. What brought on the melancholic fidelity to Derrida's texts, themes, and rhetorical registers, and the accompanying, albeit implicit, self-debasements, the denial of the worth of one's own work, language, and interests silently subtending exegetical

(c) 2015 Adam Rosen-Carole

http://www.kritike.org/journal/issue 16/rosen-carole june2015.pdf

ISSN 1908-7330

(cc) BY-NC-ND 
fixation and rhetorical assimilation, was, I suspect, the loss of the specter of Derrida hovering over the academic scene, or over culture more broadly the loss, then, of a promising cultural force keeping in check tendencies to metaphysical extravagance and inscribing at least a moment of hesitation and a pang of bad conscience, if not second thoughts, in those who would pursue "obviously deconstructable" discourses or practices. And if, following Freud strictly, melancholia presupposes a narcissistic object choice, one might wonder about what was lost with the loss of Derrida. Some of our grandiosity perhaps? A support for ressentiment-fueled fantasies? What these melancholic trends perhaps suggest is that what was lost was the promise of Derrida, a promise unilaterally ascribed to him (though he did little to resist this ascription, and so is, in a way, responsible for it), the promise to make the academy, and perhaps culture more broadly, safe for our unconventional interests, our enthusiasms and creative energies, for our more or less unruly impulses. His promise, which he never made but by which he was bound, was to make the world hospitable, or more hospitable, to the impertinence or extravagance of thought, the savagery of thinking. But of course it wasn't, indeed couldn't be, Derrida who was responsible for the relative hospitability of the academy and of cultural practice generally to non-hegemonic interests. To be sure, Derrida's magisterial intellectual accomplishments and writerly exemplarity, along with his celebrity, exerted an impressive influence on the academic world, encouraging tolerance and even, within limited sectors, enthusiasm for forms of thought and expression that would not have so readily gained a hearing, and perhaps would never have been risked in the first place, perhaps not even entertained, without him. But this impact, however impressive, is not to be overestimated. Perhaps what was lost then was, in part, the illusion of hospitability: the faith and hope misting over our vision of the propitiousness of contemporary academic, and more broadly, cultural, practice for unruly and counter-hegemonic interventions. Perhaps what this faith and hope, this promise, allowed us to forget, or neglect, is that, to amplify a thought of Benjamin's, "the attempt must be made [ever-]anew to wrest tradition away from a conformism that is about to overpower it." 1 As Derrida's death paradoxically eventuated in the dissolution, or at the very least, the diminishment, of his cultural specter - this would be the scenario of the death of the primal father, or of Moses, in reverse-perhaps what was lost with his death was a fantasy support that had been sustaining the mutual admiration society, in short, the academic insularity that had grown up around or in view of his work.

\footnotetext{
${ }^{1}$ Walter Benjamin, "Theses on the Philosophy of History," in Illuminations: Essays and Reflections, ed. by Hannah Arendt, trans. by Harry Zohn. (New York: Schocken, 1969), 255.

(C) 2015 Adam Rosen-Carole http://www.kritike.org/journal/issue 16/rosen-carole june2015.pdf ISSN 1908-7330 


\section{DEMANDING POLITICS}

These speculations aside, my central concern is with the experience of Derrida's promise and its sources; basically, the way his writings draw, or drew, their enthusiasts into a realm where the topics of concern hover in their potentiality appear unfinished, unsettled, indefinitely capable of more. My question, in short, is this: Is this how we would like to imagine ourselves? To experience Derrida's texts is to experience a slipping free from the grip of traditional authority as much as from the self-arrogated authority of the contemporary; it is to be present to the spontaneous interruption of seemingly settled oppositions, conceptual entailments, and horizons of ambition; it is to experience the startle of unprecedented insight, and innovative, unanticipated and intriguingly opaque, developments; generally, to experience Derrida's texts is to experience the unbinding of what had seemed bound by law. The experience of contingency as the experience of possible agency, of indeterminacy as intrigue, of aporia as re-beginning-an experience of initiation: This is Derrida's promise. Coming undone in the effort to reconsolidate, thus permanently available to the unforeseen; unlimitedly exposed to the event of the future and the inheritance of the immemorial past; constitutively unsettled and undecided, indeed undecidable, and more, interestingly incomplete, always already given over to adventure; inherently excessive, over teeming with potential, thus, in a word, promising - Is this how we would like to imagine ourselves? Basically, as determined but undetermined, historical yet free? You might say that we must be so. But I wonder whether we are capable of it.

Under conditions of neoliberalism, which is to say, when institutionally enshrined pressures toward privatization, deregulation, and financialization conduce to the erosion of anything even resembling substantial ethical life, let alone political self-determination, and even make the liberal orientation toward individuation, that is, toward the accomplishment of a life through the lifelong development and active embodiment of an integrated structure of normative priorities, but an anachronistic fantasy, or a piece of ideology; when the confidence in upward mobility, meritocracy, job security, social equality, and enduring intimacy gives way to the experience of unrelieved precarity and a reorientation toward surviving, just getting through or staying afloat amidst the ongoing crisis, or series of disjointed crises, that ordinary life has devolved into; when good life fantasies fray under the pressure of imperatives to constantly adjust to the inscrutable conditions of survival, when energies are consumed by the need for hypervigilant attention to these ever-altering conditions, and normative enthusiasms give way to the depressive realism of survival mentalities; when the hope that one's life might amount to something succumbs to attrition attending the dissolution of the institutional and intersubjective conditions for self-realization, let alone political self-

(c) 2015 Adam Rosen-Carole

http://www.kritike.org/journal/issue 16/rosen-carole june2015.pdf

ISSN 1908-7330

(c) $)$ BY-NC-ND 
determination; generally, when confidence in the capacity to accomplish a life, to lead a life rather than be pushed and pulled by inscrutable episodic forces contracts into frenetic scrambling to stay afloat by perpetual adjustment, that is, gives way to the depressive mania of accumulating aptitudes in the hope that one might have something to offer the oppressors; then, under these highly compromised conditions of possibility, the allure of Derrida's promise might make itself felt with an extraordinary intensity. It is not for nothing that Derrida's promise really began to have its impact with his American reception in the $80 \mathrm{~s}$, which is to say, at precisely the moment when neoliberalism was on the ascendant, and peaked in the 90s, when the fantasies supporting enthusiasm about neoliberalism crumbled in the face of its harsh realities.

Here a reference to Marx seems apposite. This is Marx, from The German Ideology:

The production of ideas, of conceptions, of consciousness, is ... directly interwoven with the material activity and the material intercourse of men .... Conceiving, thinking, the mental intercourse of men, appear ... as the direct efflux of their material behavior. The same applies to mental production as expressed in the language of politics, laws, morality, religion, metaphysics, etc. of a people. Men are the producers of their conceptions, ideas, etc. - real, active men, as they are conditioned by a definite development of their productive forces and of the intercourse corresponding to these, up to its furthest forms. Consciousness can never be anything else than conscious existence, and the existence of men is their actual life-process. If in all ideology, men and their circumstances appear upsidedown as in a camera obscura, this phenomenon arises just as much from their historical life-process as the inversion of objects on the retina does from their physical life-process.

In direct contrast to German philosophy which descends from heaven to earth, here we ascend from earth to heaven. That is to say, we do not set out from what men say, imagine, conceive, nor from men as narrated, thought of, imagined, conceived, in order to arrive at men in the flesh. We set out from real, active men, and on the basis of their real life-process we demonstrate the

(C) 2015 Adam Rosen-Carole http://www.kritike.org/journal/issue 16/rosen-carole june2015.pdf ISSN 1908-7330 
development of the ideological reflexes and echoes of this life-process. The phantoms formed in the human brain are also, necessarily, sublimates of their material life-process, which is empirically verifiable and bound to material premises. Morality, religion, metaphysics, all the rest of ideology and their corresponding forms of consciousness, thus no longer retain the semblance of independence .... Life is not determined by consciousness, but consciousness by life. In the first method of approach the starting-point is consciousness taken as the living individual; in the second method, which conforms to real life, it is the real living individuals themselves, and consciousness is considered solely as their consciousness. ${ }^{2}$

Or, a little more succinctly:

Since the Young Hegelians consider conceptions, thoughts, ideas, in fact all the products of consciousness, to which they attribute an independent existence, as the real chains of men (just as the Old Hegelians declared them the true bonds of human society) it is evident that the Young Hegelians have to fight only against these illusions of consciousness. Since, according to their fantasy, the relationships of men, all their doings, their chains and their limitations are products of their consciousness, the Young Hegelians logically put to men the moral postulate of exchanging their present consciousness for human, critical or egoistic consciousness, and thus of removing their limitations. This demand to change consciousness amounts to a demand to interpret reality in another way, i.e. to recognise it by means of another interpretation. The Young-Hegelian ideologists, in spite of their allegedly 'world-shattering' statements, are the staunchest conservatives. The most recent of them have found the correct expression for their activity when they declare they are only fighting against 'phrases.' They forget, however, that to these phrases they themselves are only

2 Karl Marx, The German Ideology [1845-6/1932] (Progress Publishers, 1968), in $<$ https://www.marxists.org/archive/marx/works/1845/german-ideology/ch01a.htm>.

(c) 2015 Adam Rosen-Carole http://www.kritike.org/journal/issue 16/rosen-carole june2015.pdf

ISSN 1908-7330

(c) BY-NC-ND 
opposing other phrases, and that they are in no way combating the real existing world when they are merely combating the phrases of this world. ${ }^{3}$

In Derrida's writings, ideas do what we perhaps cannot, or not so readily: namely, survive and transform, assimilate, absorb, integrate and differentiate endlessly, come apart and recompose without breaking down or losing sense altogether. Derrida's writings are perhaps, or rather, have perhaps become, repositories of our fantasy selves under conditions of neoliberalism, screens upon which our fantasy selves are, under such conditions, anxiously projected, enthusiastically encountered, but also preserved from the ruination they would befall were one to more directly engage them, attempt to live them out. These writings are, thus, in a way, fantasies of neoliberalism, or have become such. Is it then something like what Marx describes as German ideology that is experienced as so enticing and vexing in these eminently and exquisitely French, which is to say, goodlife-inclined or good-life-embodying texts? Is contemporary French philosophy, as mediated by its American reception, now the locus of German ideology?

Whence and what to make of the experience of Derrida's promise? Whence and what to make of Derrida's counter-metaphysical, yet, from Marx's perspective, idealistic, thus still metaphysical projection of survivability and transformability? Whence and what to make of the metaphysical claim that iteration implies unremitting exposure to, even the necessity of, alteration? Concepts in Derrida's writings are exposed in advance to unpredictable developments while at once inscribed inexorably by their history of production and reception, thus are unlimitedly exposed to the future yet unbreakably bound to the past. Might some of the allure, some of the promise of these writings have to do with the sense, or the wish, that if this is true of concepts, then perhaps it is something of which we are capable? Derrida insists that the impossible happens all the time. Conceptually, ideationally, sure enough. But practically, matters are less certain. Is the insistence that the impossible happens all the time not an expression of the perspective of privilege, indeed of the extraordinary privilege of the globetrotter? Is Derrida's promise not a fantasy of liquid modern life?

Derrida's writings are, on the one hand, clear and precise in their conceptual architecture, ambitions, and insights; indeed, they can be annoyingly monotonous, even monomaniacal: undecidability, autoimmunity, antinomy, aporia, contradictory injunction or double injunction, difference, double constraint, double bind-all name, more or

${ }^{3}$ Ibid.

(C) 2015 Adam Rosen-Carole http://www.kritike.org/journal/issue 16/rosen-carole june2015.pdf

ISSN 1908-7330 
less, the same. Derrida is always pulling off the same trick: demonstrating that the insurpassable metaphysical drive toward the origin, the arche, the foundation, the elemental, or the proper is sourced in, thus, interrupted in advance by the anxiety of processual differentiation which it attempts to allay through the resolution of the event of differentiation into clear cut, hierarchically organized oppositions. But on the other hand, Derrida's writings are errant creatures, full of surprises and overteeming with unresolved tensions: frequently given to detours, studded by enticing hints and undeveloped gestures, prone to suspensions of argumentative and narrative development, suffused with prominent details that seem inassimilable to their overall trajectory, prone to surprising philosophical and rhetorical turns and other ways of keeping our interest peaked on edge, anticipatory of a final moment of revelation in the light of which all that precedes it would be retrospectively revealed as a coherent whole ... which of course never comes, rather, is always forthcoming. They are highly regulated, integrated, and readily identifiable yet uncoordinated, indeed sort of random, or idiosyncratic, both semantically and syntactically; at least stylistically identifiable, but in shambles, turbulent, ever on the verge of coming apart, disarrayed. Can we not see ourselves in the image of these texts? Can we not make out our desires and fears? Unremittingly exposed to unanticipatable developments yet remarkably repetitive, somehow integrated, even fixated, yet very loosely assembled: Is this not how we desire to see ourselves; indeed, we cannot but desire to see ourselves under neoliberal conditions, and at once, is this not how fear that we might, in fact, be? Might Derrida's promise be, to some extent, a symptom: the simultaneity of desire and anxiety supporting their mutual occlusion? Might the experience of the promise of these writings not shield us from our condition, that is, from both our desire and our anxiety, by enacting, ideationally, the ideal life under conditions of neoliberalism? Might their contact with what is unbearable about our fate, that is, our unrelieved precarity that somehow coordinates with an oppressive monotony, condition their capacity to elicit enthusiasm over the ideal presentation of this fate, its emphatic affirmation?

Derrida's writings are, unlike we, frayed and depressed denizens of neoliberalism, tireless. They are as tireless as we would like ourselves to be, or tireless in the way we would like to be: tirelessly intrigued and ambitious rather than tirelessly inventive in our scrambling to accommodate the obscure and ever changing conditions of survival. That the most remarkable qualities of Derrida's writings, such as sustained enigma or undecidability, can function defensively, protecting from boredom or from a despairing acknowledgement of a pervasive boredom, as well as from the anxiety of overproximity, thus from the experience of being overwhelmed, and can protect against detachment, thus protect the promises of the object one cannot

(c) 2015 Adam Rosen-Carole

http://www.kritike.org/journal/issue 16/rosen-carole june2015.pdf

ISSN 1908-7330

(c) $)$ BY-NC-ND 
bear to let go, and so defend against acknowledging the consequences of laying down one's defenses - all of this is perhaps related to the promise of Derrida's writings, a material-fantasmatic condition for Derrida's writerly practice as much as for its enthusiastic reception. Is it merely incidental that so much in these writings remains in a state of suspended development, remains, thus, as potential? Might the overabundance of potential be in some way, or in certain cases, an avoidance of carrying thought that thereby staves off disappointment? And so it keeps us bound to the disappointments of the present via the imagination of their possible redemption? Is there too much future in Derrida? Too much enthusiasm? Too much interest? And speculation? Too much promise, then? There is nothing that Derrida cannot make fascinating; indeed, his fascination is contagious. But to what extent is such fascination itself compensation for a dull yet exorbitantly anxious actuality?

The experience of Derrida's writings is the experience of a tolerable and so desirable dissonance, a lightly discomfiting, because aestheticized, frenzy. As Marcuse puts the point in his essay, Affirmative Culture, "only in art has bourgeois society tolerated its own ideals and taken them seriously as a general demand. What counts as utopia, phantasy, and rebellion in the world of fact is allowed in art. There affirmative culture has displayed the forgotten truths over which 'realism' triumphs in daily life. The medium of beauty decontaminates truth and sets it apart from the present. What occurs in art occurs with no obligation." 4

"Deconstruction," Derrida once remarked, "is seen as hyperconceptual, and indeed it is; it carries out a large-scale consumption of concepts that it produces as much as it inherits - but only to the point where a certain writing, a writing that thinks, exceeds the conceptual 'take' and its mastery. It therefore attempts to think the limit of the concept; it even endures the experience of excess; it lovingly lets itself be exceeded." ${ }^{5}$ Derrida's writerly practice is certainly extravagant. A patient and protracted, rigorously immanent conceptual labor, to be sure, never heedless of the official ambitions and self-understandings or authoritative, traditional interpretations of the texts under scrutiny, or simply reckless in its enthusiasm for exposing aporia there where a text or tradition seems most self-confident, self-centered, or fully accomplished. Yet this writerly practice is nevertheless nothing less than exorbitant, indeed somewhat itinerant in its associational expansiveness and more than ambitious in its principles of construction. Derrida's writings are, one might say, extra-clinical enactments

\footnotetext{
${ }^{4}$ Herbert Marcuse, "Affirmative Culture," in Art and Liberation: Collected Papers of Herbert Marcuse, Volume Four, ed. by Douglas Kellner (New York: Routledge 2007), 100.

${ }^{5}$ Jacques Derrida and Elisabeth Roudinesco, For What Tomorrow ... A Dialogue, trans. by Jeff Fort (Stanford: Stanford University Press, 2004), 5.
} 


\section{2}

DEMANDING POLITICS

of the fundamental rule of psychoanalysis to say everything that comes to mind, but without the focusing force of transference, and without an analogue to the assumption of unconscious determination. Their extraordinary capacity to sustain exposure to and integrate without thetically or thematically flattening, thus to assemble, or constellate, fleeting impressions and potentially misleading or distracting, certainly unauthorized impressions and connections with concerted, conceptually focused, philosophically pointed and pertinent, immanently critical readings is both their glory and the source of a worry. Derrida's interest in implicating the serious in the frivolous and vice versa, or more broadly, what one might call his writerly shamelessness, evinces an exorbitant narcissism, a writerly ethos of repudiating repudiation, a "hyperconceptual" penchant for excess that seems to both condition his truly unparalleled and startlingly acute insights, but also to suffuse his texts with so many loose threads and frayed edges that these texts cannot but seem suspiciously underdeveloped, or brittle in their very grandiosity-as if something were being hidden, or perhaps avoided, by means of their seemingly unlimited capaciousness. "Beauty," says Marcuse, again in Affirmative Culture, "is fundamentally shameless. It displays what may not be promised openly and what is denied the majority." 6 One way to phrase this worry would be to ask whether Derrida's writerly impudence, the iconoclastic dimension of deconstruction, squares with the requirement of mutual authorization to critique constitutive of normativity, or with the normative conditions of meaningful content generally. If Derrida's writerly practice is as given to unregulated and unregulatable excess as it seems, might there be an at once anti-democratic and philosophically problematic aspect to its seemingly anti-authoritarian ethos of unlimited affirmation? Derrida unconditionally affirms one aspect of democracy, namely, the right to unlimited critique, which he equates with the university without condition, but not so much the egalitarian dimension of democracy, the requirement of mutual authorization.

The question is whether the "consumption of concepts that it produces as much as it inherits" renders deconstruction, by virtue of its nominalism, a form of nihilism - a creative consumerism. And the further question is: Is creative consumerism the most that we can hope for ourselves? Is an agile, creative consumerism the best sustainable good life fantasy on offer? Is the last gasp of fantasies of the good life on the verge of attrition?

Keeping in mind the earlier suggestion about disrespect, as well as Marcuse's claim that "What occurs in art occurs with no obligation," let me conclude by suggesting that Derrida's writings perhaps give new meaning to an old line by Walter Benjamin: "there is no document of civilization that is

${ }^{6}$ Marcuse, “Affirmative Culture," 100.

(C) 2015 Adam Rosen-Carole

http://www.kritike.org/journal/issue 16/rosen-carole june2015.pdf

ISSN 1908-7330

(c) $)$ BY-NC-ND 
not at the same time a document of barbarism. ${ }^{\prime 7}$ It is Derrida's barbarism that I most admire and worry over.

Department of Philosophy, Rochester Institute of Technology, United States

\section{References}

Benjamin, Walter, "Theses on the Philosophy of History," in Illuminations: Essays and Reflections, ed. by Hannah Arendt, trans. by Harry Zohn. (New York: Schocken, 1969).

Benjamin, Walter, "Eduard Fuchs: Collector and Historian," in New German Critique, 5 (Spring 1975).

Derrida, Jacques and Roudinesco, Elisabeth, For What Tomorrow ... A Dialogue, trans. by Jeff Fort. (Stanford: Stanford University Press, 2004).

Marcuse, Herbert, "Affirmative Culture," in Art and Liberation: Collected Papers of Herbert Marcuse, Volume Four, ed. by Douglas Kellner (New York: Routledge, 2007).

Marx, Karl, The German Ideology [1845-6/1932] (Progress Publishers, 1968), in $<$ https://www.marxists.org/archive/marx/works/1845/germanideology/ch01a.htm>.

7 Benjamin, "Theses on the Philosophy of History," 256; Walter Benjamin, "Eduard Fuchs: Collector and Historian," in New German Critique, 5 (Spring 1975), 35. (translation modified)

(C) 2015 Adam Rosen-Carole http://www.kritike.org/journal/issue 16/rosen-carole june2015.pdf ISSN 1908-7330 